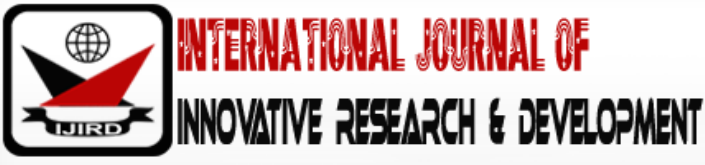

ISSN 2278 - 0211 (Online)

\section{Dimensions of Computer-Based Internet Technology Technophobia among Agricultural Extension Personnel in Akwa Ibom State, Nigeria}

\begin{tabular}{|c|}
\hline Iniobong A. Akpabio \\
Professor, Department of Agricultural Economics and Extension, University of Uyo, Nigeria \\
Joan E. Cyril \\
Ph.D. Candidate, Community and Social Development Project in Akwa Ibom State, Nigeria \\
Emem B. Inyang \\
Consultant, Department of Agricultural Economics and Extension, University of Uyo, Nigeria \\
Dr. Unyime R. Etuk \\
Senior Lecturer, Department of Agricultural Economics and Extension, University of Uyo, Nigeria
\end{tabular}

\section{Abstract:}

The study was carried out to examine the dimensions of Computer-Based Internet Technology (CBIT) technophobia among extension personnel in Akwa Ibom State. Specifically, it identified respondents: personal characteristics; incidence of CBIT technophobia, level of CBIT technophobia and identified factors influencing CBIT technophobia. The study hypotheses tested: the relationship between personal characteristics and the levels of CBIT technophobia and the difference in CBIT technophobia between Field Extension Personnel (FEP) and Supervisory Extension Personnel (SEP). Simple random sampling technique was used to select respondents. Data was generated from primary source through a structured questionnaire and analysed using descriptive and inferential statistics. Findings show that $57.8 \%$ of the respondents were male, $91.7 \%$ were married and their mean age was 43 years. Also, while $79.5 \%$ respondents constituted FEP, $64.4 \%$ were graduates and the mean household size was six (6). Mean monthly income of respondents was revealed to be N73, 108.00, while $62.8 \%$ had no formal computer training. It was also revealed that 83. $9 \%$ respondents had moderate CBIT technophobia, while predisposing factors to CBIT technophobia were revealed to encompass; human, operational, learning anxiety, lack of exposure and experience, technology, environment and self -efficacy indices. Hypotheses revealed that educational level influenced CBIT technophobia, although no significant difference was observed between FEP and SEP respondents with regard to CBIT technophobia. The study concluded that level of education influences CBIT technophobia. It was recommended that training and exposure to the use of CBIT should be given to extension personnel to ameliorate the effect of CBIT technophobia.

Keywords: Technophobia, computer-based internet technology, field extension personnel, supervisory extension personnel

\section{Introduction}

With the advent of the technology, computer and related technologies, technophobia emerged. The word technophobia is derived from Greek Techne meaning arts, skill or craft and Phobos, meaning fear or aversion. It is a complex interplay of behavioural, emotional and attitudinal components to the fear of computer and complex technologies (Wang, Shu and Tu 2008, and Sami and Pangannaiah 2006). It is the constant and persistent fear of technology and in greater depth; it is the feeling of severe anxiety associated with using anything technologically complex and the anxiety associated with the perceived effects of advanced technology (Ben-Jacob and Liebman, 2009 and Ha, Tom Gisli, 2011). Rheingold (2002) identified the causes of technophobia to include: perception of the technology in terms of the complexity of the technology; demographic variation that shows that younger people adopt new technologies better than older generations and the belief that with new technology, people might become nervous due to the changes and disruptions it may introduce into their lives.

The emergence of Information and Communication Technologies (ICTs) in all fields of human endeavour came with dimensions of technophobia. Ha et.al (2011) observed that the development of the internet-based technologies and sophisticated mobile phones will inevitably lead to more people becoming technophobic. The growing concern for development practitioners is the drive to eradicate the scourges of poverty; diseases, illiteracy and food insecurity through the 
mechanism of ICTs. By this, ICTs and by extension the use of computer-based internet technology (CBIT) in extension communication delivery can contribute to the reduction of poverty and hunger of objectives 1 and 2 of the Sustainable Development Goals (SDG). Ezeano, Matthew -Njoku, Ezeano and Isife (2011) asserted that ICTs when networked with the internet will enable collaborative and interactive learning which can improve the efficiency and effectiveness of technology delivery to farmers. This therefore means that extension personnel must be abreast with current technologies for sourcing and dissemination of current technologies to farmers alongside the traditional Training and Visit (T and V) system. Thus, CBIT facilities, applications and their uses in agricultural advisory services are necessary to confront the challenges of food security for the ever-increasing human population

The availability of CBIT facilities as smart phones, laptops and their various web 2 applications behoves that the extension personnel becomes knowledgeable and proficient in the delivery of real- time information to farmers and clients. Thus, CBITs are known to play a vital role in the transfer of high-tech agricultural technologies from across the globe to the farmers' field; and studies have indicated that CBITs can enhance teaching and learning (Nyirongo, 2009 and Zinn, 2009). According to Omotayo (2011) CBIT in extension delivery includes effective use of ICT, information networks, the internet, expert's systems, multimedia learning and computer-based training systems; to improve access to information and enable information sharing among extension stakeholders. All modes of anxiety exhibited by extension personnel in the quest to effectively incorporate this application in their advisory role have not been fully explored. Even as the world is perceived today as being technology driven, CBITs are gradually finding its way into extension routine work. It is anticipated that this development will be welcomed with some level of anxiety, fear or resistance. The inability to cope with emerging internetbased technologies in a healthy manner has been reported by Sami and Pengannaiah (2008). Although various researchers (Riggs, 2010; Fidiji, 2011 and Salau 2013) have studied the application of ICTs in extension communication, there is little or no focus on the aspect of technophobia of CBIT by extension personnel in Akwa Ibom state.

Studies on technophobia in Nigeria revealed that technophobia has been the major hindrance of academic staff to effectively explore the use of ICT for teaching and learning in universities in northern Nigeria (Ahmad, Kamba and Usman, 2012). Similarly, Olufemi and Oluwatayo (2014) reported that technophobia due to poor computer knowledge affected the performance of students who sat for University Matriculation Examination (UME) using the Computer Based Test (CBT). Limited Study on technophobia in Akwa Ibom State has been conducted, with reference to Uyo zone of ADP (Ubom, 2015). Therefore, a wider scope of the study in the State becomes imperative. In essence, it may be necessary to seek to ascertain more facts with regards to the socio-economic characteristics of extension personnel in the study area, their level of CBIT technophobia, incidents of technophobia and clarification, with regards to various factors influencing CBIT technophobia among extension personnel.

In the process, it also becomes imperative to ascertain the existence or otherwise, of a significant relationship between personal characteristics of Akwa Ibom ADP personnel and their level of CBIT technophobia; and the existence or otherwise of a significant difference in the level of CBIT technophobia between Field extension personnel (FEP) and Supervisory Field Personnel (SEP) of Akwa Ibom ADP.

\section{Theoretical Framework}

Social learning theory expectancy model and Social Cognitive Theory were the models used to assess technophobia among the study respondents. These theories explain that, previous negative experiences with technology activate CBIT anxiety and a negative internal dialogue that deride an individual's ability and confidence in successfully using the CBIT compound the anxiety associated with the use of technology. Social Cognitive Theory (SCT) also recognizes the existence of a continuous reciprocal interaction between the environment in which an individual operates, his or her cognitive perceptions (self-efficacy and outcome expectations), and behaviour. Central to SCT is self-efficacy that is viewed both as a necessary condition for CBIT use, in other words, individuals who do not believe they have the capability will not likely attempt to use technology.

\section{Methodology}

This study was conducted in Akwa Ibom State, Nigeria. The State lies between Latitudes $4^{\circ} 33^{\prime \prime}$ N and 503" N and Longitudes $7^{\circ} 25^{\prime \prime} \mathrm{E}$ and $8^{\circ} 25^{\prime \prime} \mathrm{N}$. Akwa Ibom State, currently; has an estimated population of over five million. The study population consisted of all the extension personnel in Akwa Ibom State. ADP extension personnel in the six zones were purposively chosen for this study taking into cognizance the fact that the six zones have the same organisational structure, working conditions and ICT facilities. Through simple random sampling technique, 192 extension personnel were selected from the six zones as the study sample, although 180 questionnaires were validated and used for the study. Structured questionnaire was used to elicit information from the respondents. The data were analysed using descriptive (means, frequencies, percentages, ranks, composite index) and inferential (factor analysis, chi-square, t-test) statistics. 


\section{Results and Discussion}

\subsection{Personal Characteristics of Respondents}

Results (Table 1) indicate that $57.8 \%$ of the respondents were male while $42.2 \%$ were female. This implies that there are more male extension personnel in the study area. The observed male dominance on the Table cannot be unconnected with the fact that agricultural profession is male-dominated in Nigeria (Lawal-Adebowale and Oyekunle, 2014). Also, a large proportion (49.4\%) of the respondents was within the age range of $41-50$ years followed by 40.0 percent who were between 31-40 years age range. The mean age of the respondents was 42.56 years. This suggests that most of the extension agents were young and in their middle age and could be dynamic with enough vigour to execute extension tasks. The majority (91.7\% - 165) of the respondents were married, implications are that respondents were married men and women, saddled with family responsibilities. Data in Table 1 also reveals that majority (63.9\%) of the respondents were Field Extension Personnel (FEP), a large proportion (64.4\%) of whom had acquired B. Sc/HND as the highest level of education. This could suggest possession of a first degree as the pre-requisite for employment and promotion in public organizations. Also, it is a specialized field that requires highly trained personnel. Household size of respondents shows a mean household size of six, indicating that most of the respondents had medium household sizes. Estimated monthly income level in Table 1 indicates that respondents mean monthly income was $\$ 73,108.00$ with a large proportion (46.11\%) earning between $\$$ $71,000.00$ - 110,000.00. This implies that most of the personnel were earning above the national minimum wage of 18,000 per month. The result reveals that $62.8 \%$ of the respondents had not experienced any form of computer training, indicating that more than half of the respondents were non-computer literate.

\subsection{Incidence of CBIT Technophobia among Respondents}

\subsubsection{Distribution of Respondents Based on the Incidence of CBIT Technophobia}

Incidence analysis on Table 2 reveals the severity of the incidence of CBIT technophobia and responses of extension personnel on perceived CBIT technophobia. The three statements that indicate the highest incidence of CBIT technophobia were:

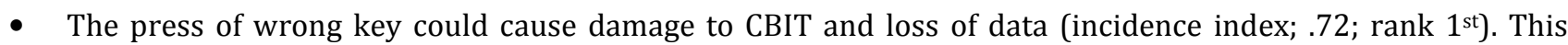
implies that technophobia among the respondents is in part due to the anxiety respondents feel towards handling of the technology, where they consider that the press of the wrong button could result into loss of data. A similar observation was reported by Udom (2015).

- With time and practice I will not be relaxed using CBIT as I am with other devices (incidence index: .58; rank $\left.2^{\text {nd }}\right)$. The high incidence of technophobia expressed by respondents on this item could suggest that subjects in the study area will avoid learning something new probably due to the perceived difficulty and the perceived risk associated with learning. Similarly, respondents may express high incidence of technophobia as technology continue to evolve and their age tends to make them more technophobic than younger respondents (Rheingold, 2002).

- I feel CBIT are necessary tools in both farm demonstration and work settings (Incidence index; .50; rank 3rd). This finding, on this high incidence of CBIT technophobia could suggest that the skill and competence required in using CBIT is still low among extension personnel in the study area. The effect of this implies that respondents are not inclined to explore the internet as an alternative source of information and their work nature is predominantly face to face and highly dependent more on the use of print media.

Similarly, items where respondents indicated low incidence of CBIT technophobia were:

- I am not looking forward to using a CBIT in my job (incidence index .28; rank $11^{\text {th }}$ )

- I feel CBIT are not necessary in our work setting (incidence index .28; rank 11 ${ }^{\text {th }}$ ). The incidents of CBIT technophobia based on the above items have bearing on the respondents' level of CBIT utilization. The low level of use of CBIT for professional use among extension practitioners has been reported and is largely due to lack of awareness, skill and competence. This could also suggest that despite expressing low level of anxiety, respondents are sceptical about the usefulness of CBIT in extension work as well as the issue related to privacy and technophobia. The response on these items may be due to the argument that surrounds the utility of global knowledge in agriculture, lack of infrastructure for CBIT use and psychological barriers. Others were:

- I feel uneasy about using CBIT (incidence index .28; rank $11^{\text {th }}$ ). This could suggest that respondents see CBIT tools as desirable in augmenting extension work but do not possess the skills to effectively use these items. Indications are that technology will be adopted when people perceive the technology to be useful in enhancing one's job performance and when they perceive the technology as being easy to use;

- I have avoided CBIT because they are unfamiliar and somewhat frightening (incidence index .26; rank 14). This implies that lack of training contributed to this level of agreement; as more than half (62.8 percent) of the respondents did not experience any formal computer training (Table 1) and this could suggest that respondents do not use CBIT in the dissemination of information. Secondly, the expressed level of CBIT 
technophobia and unfamiliarity with CBIT could be as a result of poor internet facilities and power supply in the rural area where they operate; and,

- I feel I will not be able to keep up with the advances in computer field (incidence

index .25; rank 15) This indicates that respondents' level of CBIT technophobia is based on the perception that CBITs are complex (Ha et al., 2011). This observation is further supported by Rheingold (2002) who indicated that when people perceive a technology to be complex and advanced, it is more likely they would become technophobic and may avoid the use of such technology despite its perceived benefits.

Item Variable Frequency Percentage Mean

\begin{tabular}{|c|c|c|c|c|}
\hline Item & Variable & Frequency & Percentage & Mean \\
\hline \multirow[t]{3}{*}{1} & Sex & & & \\
\hline & Male & 104 & 57.8 & \\
\hline & Female & 76 & 42.2 & \\
\hline \multirow[t]{5}{*}{2} & Age (years) & & & \\
\hline & $21-30$ & 04 & 2.22 & 42.56 \\
\hline & $31-40$ & 72 & 40.01 & \\
\hline & $41-50$ & 89 & 49.44 & \\
\hline & $51-60$ & 15 & 8.33 & \\
\hline \multirow[t]{4}{*}{3} & Marital status & & & \\
\hline & Single & 12 & 6.67 & \\
\hline & Married & 165 & 91.67 & \\
\hline & Widowed & 3 & 1.66 & \\
\hline \multirow[t]{8}{*}{4} & Job Status & & & \\
\hline & $\mathrm{ZM}$ & 6 & 3.3 & \\
\hline & ZEO & 4 & 2.2 & \\
\hline & SMS & 27 & 15.0 & \\
\hline & BES & 28 & 15.6 & \\
\hline & BEA & 20 & 11.1 & \\
\hline & EA & 91 & 50.6 & \\
\hline & Others & 4 & 2.2 & \\
\hline \multirow[t]{4}{*}{5} & Educational level & & & \\
\hline & OND/NCE & 46 & 25.6 & \\
\hline & $\mathrm{HND} / \mathrm{BSC}$ & 116 & 64.4 & \\
\hline & $\mathrm{MA} / \mathrm{MSc}$ & 18 & 10.0 & \\
\hline \multirow[t]{5}{*}{6} & Household size & & & \\
\hline & $0-5$ & 88 & 48.90 & 5.76 \\
\hline & $6-10$ & 90 & 50.00 & \\
\hline & $11-15$ & 01 & 0.55 & \\
\hline & $16-20$ & 01 & 0.55 & \\
\hline \multirow[t]{6}{*}{7} & Estimated monthly income level (N) & & & \\
\hline & $10,000-40,000$ & 15 & 8.33 & $73,108.92$ \\
\hline & $41,000-70,000$ & 74 & 41.11 & \\
\hline & $71,000-110,000$ & 83 & 46.11 & \\
\hline & $111,000-140,000$ & 06 & 3.33 & \\
\hline & $141,000-200,000$ & 02 & 1.12 & \\
\hline \multirow[t]{3}{*}{8} & Attended Computer Training & & & \\
\hline & Yes & 67 & 37.2 & \\
\hline & No & 113 & 62.8 & \\
\hline
\end{tabular}

Table 1: Personal Characteristics of the Respondents (N: 180) 


\begin{tabular}{|c|c|c|c|c|c|c|}
\hline Item & $\begin{array}{c}\text { Level of Agreement with the Following } \\
\text { Statements }\end{array}$ & $\mathbf{D}$ & NS & $\mathbf{A}$ & $\begin{array}{l}\text { Incidence } \\
\text { Index }\end{array}$ & Rank \\
\hline 1 & $\begin{array}{l}\text { I don't feel confident about my ability to interpret } \\
\text { CBIT manual. }\end{array}$ & 62.2 & 21.1 & 16.7 & 0.38 & 7th \\
\hline 2 & I am not looking forward to using a CBIT in my job & 71.7 & 16.1 & 12.2 & 0.28 & 11th \\
\hline 3 & The challenge about learning CBIT is not exciting & 58.3 & 25.0 & 16.7 & 0.42 & 5 th \\
\hline 4 & $\begin{array}{l}\text { With time and practice I will not be relaxed using } \\
\text { CBIT as I am with other devices }\end{array}$ & 41.7 & 18.9 & 39.4 & 0.58 & 2nd \\
\hline 5 & $\begin{array}{l}\text { I feel I will not be able to keep up with the advances } \\
\text { in computer field }\end{array}$ & 75.0 & 18.9 & 6.1 & 0.25 & 15th \\
\hline 6 & I feel uneasy about using CBIT & 71.1 & 15.0 & 12.9 & $0 . .28$ & 11th \\
\hline 7 & $\begin{array}{l}\text { I hesitate to use CBIT for fear of making mistake } \\
\text { that I cannot correct }\end{array}$ & 67.8 & 15.0 & 17.2 & 0.32 & 10th \\
\hline 8 & I feel CBIT are not necessary in our work setting & 71.7 & 16.7 & 11.6 & 0.28 & 11th \\
\hline 9 & $\begin{array}{l}\text { I have avoided CBIT because they are unfamiliar } \\
\text { and somewhat frightening }\end{array}$ & 74.4 & 12.8 & 12.8 & 0.26 & 14th \\
\hline 10 & $\begin{array}{l}\text { I feel CBIT are necessary tools in both farm } \\
\text { demonstration and work settings }\end{array}$ & 33.4 & 16.1 & 50.5 & 0.50 & $3 r d$ \\
\hline 11 & $\begin{array}{l}\text { CBIT makes me uncomfortable because I do not } \\
\text { understand it. }\end{array}$ & 61.1 & 18.9 & 20.0 & 0.39 & 6th \\
\hline 12 & $\begin{array}{l}\text { I think I would be able to read and interpret CBIT } \\
\text { manual }\end{array}$ & 17.8 & 16.7 & 65.5 & 0.35 & 9th \\
\hline 13 & $\begin{array}{l}\text { You have to be intelligent to understand all the keys } \\
\text { contained in CBIT }\end{array}$ & 28.3 & 16.7 & 55.0 & 0.45 & 4 th \\
\hline 14 & $\begin{array}{l}\text { The press of wrong key could cause damage to CBIT } \\
\text { and loss of data }\end{array}$ & 28.3 & 27.7 & 44.0 & 0.72 & $1 \mathrm{st}$ \\
\hline 15 & $\begin{array}{l}\text { I am not confident I can handle the advancement in } \\
\text { CBIT }\end{array}$ & 62.8 & 17.8 & 19.4 & 0.37 & 8th \\
\hline
\end{tabular}

Table 2: Distribution of Respondents According to CBIT Technophobia (N: 180)

\subsection{Respondents' Level of CBIT Technophobia}

Composite Index on Table 3 reveals that there are three categories of CBIT technophobia among the respondents in the study area. The analysis shows that majority (83.9\%) of the respondents fell into the moderate level of CBIT technophobia; $1.1 \%$ fell into low level of CBIT technophobia and $15.0 \%$ indicated high level of CBIT technophobia. The implication of this moderate (83.9\%) and high level (15.0\%) level of CBIT technophobia by respondents explain why most of the respondents do not feel at ease in using CBIT for extension work. The finding of this study is in concurrence with preliminary findings of Ubom (2015). Ahmad, Kamba and Usman (2012) indicated that technophobia has been the major hindrance of academic staff to effectively explore the use of ICT for teaching and learning in universities in northern Nigeria. The large proportion of respondents (83.9\%) in the moderate level CBIT technophobia has far-reaching implications for the extension work force and management. Care must be taken to ensure that a high proportion of this moderate group is enabled to merge into the low-level technophobia category, for improved information access and delivery to clientele. This optimal situation may be actualized by exposure to in-service CBIT-oriented training programmes and facilitatory access to CBIT tools.

\begin{tabular}{|l|l|l|l|}
\hline Interval index & Index Interpretation & Frequency & Percentage \\
\hline $0.00-0.39$ & Low technophobia & 2 & 1.1 \\
$0.40-0.69$ & Moderate technophobia & 151 & 83.9 \\
$0.70-1.00$ & High technophobia & 27 & 15.0 \\
\hline & & 180 & 100 \\
\hline
\end{tabular}

Table 3: Level of CBIT Technophobia Index of Respondents (LCBITTI) ( $N=180$ )

\subsection{Factors Influencing CBIT Technophobia}

Factors analysis on Table 4 reveals that there were seven major factors influencing CBIT technophobia among Akwa Ibom ADP personnel. These factors are as detailed below, to include:

- Factor 1- Human-related variables: This first category of components included items such as; I cannot use CBIT for farm demonstration (.630), As a VEA I don't need CBIT for field work (.715), Because of my age I prefer face to face 
method of extension (.639) and Members of my social group do not understand application of CBIT (.579). These four items loaded positively in excess of 0.5 as shown in Table 4 . These four components expressed concerns with respondents not having the skill to use CBIT for demonstration and still show preference for face to face method of extension communication. This suggests that CBIT technophobia is as a result of factors embedded in the respondents. This implies that adherence to face to face extension method; coupled with the mean (43 years) age of respondents and computer training received by only $43 \%$ of respondents can influence CBIT technophobia. The effect of this factor on the study subjects could be attributed to the fact that they are not inclined to research and their work nature is predominantly face to face communication. This finding is in conformity to Bhattacharjee and Rai (2016) who indicated that skill and competence in using CBIT is still low among researchers, extension workers and farmers in developing countries.

- Factor 2- Operational variables: This component is constituted by two items; "I find the buttons too tiny and fragile" and "I have a busy schedule to bother with CBIT" loaded positively on this factor. This implies that respondents' technophobia towards CBIT is largely due to their busy schedule and lack of interest and due to the fact that CBIT devices have tiny and fragile buttons. Respondents being busy could also result to the development of negative attitude towards CBIT. It could be suggested that effective integration of technology application should be tailored to job context and applied towards job specifications.

- Factor 3-Learning anxiety variables: Most of the items in this component relate to the apprehension experienced by respondents towards learning CBIT. This indicates that respondents exhibit some level of anxiety in learning to use CBIT. This anxiety towards learning could suggest why a high proportion of the respondents did not attend any form of computer training. This observation buttresses Ha et. al's (2011) assertion to the effect that further development of internet technologies and sophisticated mobile phones will inevitably lead to more people becoming technophobic. Furthermore, Porter and Donthun (2006) hypothesized that users will avoid learning something new due to perceived difficulty and the perceived risk associated with learning.

- Factor 4- Lack of exposure and experience variables: This component entails two items which load in excess of .05. These are; 'CBIT is difficult to use due to lack of previous training' (.785) and 'I don't have enough experience to use CBIT'(.691). Respondents' level of CBIT technophobia, in part, could be attributed to inadequate knowledge of CBIT and lack of experience in changing from the use of analogue phones to smart phones and other sophisticated CBIT facilities. This implies that computer training and experience with the use CBIT can result in lower level of technophobia.

- Factor 5- Technological variables: Two items loaded highly on this component. These items were; 'use of CBIT is dependent on one's sex' and, 'I fear the possibility of damaging the device.' This implies that CBIT technophobia is influenced by one's gender; as men and women are observed to use technology differently (Kase and Ritter, 2005). Also, Chau and $\mathrm{Hu}$ (2002) indicated that technological fear is as a result of the characteristics of the technology that make it either easy or difficult to use. They further opined that when people perceive the technology to be complex, the higher the chances of becoming technophobic and may result to avoidance in the use of a particular technology.

- Factor 6 - Environmental variable: This component Indicates that respondents alluded to the fact that technophobia is as a result of the environment and location of their operations. In essence, respondents who work in rural areas are limited in accessing ICT infrastructure and accessories that will support or promote CBIT utilization. The implication of this is the reliance on the face to face contact method of communication than the adoption of CBIT that may require regular power supply and steady network. The situation can indirectly be compounded by the advancement in the age of the respondents as middle age and elderly people might exhibit less interest in the use of hi-tech devices.

- Factor 7-Self-efficacy variables: This component is so named because respondents expressed concerns to issues related to lack of confidence. Self-efficacy is not a function of CBIT skills, but rather, what one can do with his or her skills. This implies that respondents focused on their lack of exposure to CBIT use rather than having judgment on their ability to use CBIT. The construct of self-efficacy is related to self-confidence. Thus, in explaining the relationship between age and self-efficacy, Reed, Doty and May (2005) observed that younger individuals tend to have higher levels of technology related self-efficacy beliefs than older individuals. This finding is not surprising given the widespread stereotype of older adults' inability to learn new materials, especially when the material is technology-related. This suggests that ADP personnel perceive CBIT as being difficult to use and have not been able to summon requisite courage to apply their skills to overcome the fear to use CBIT for extension work. 


\begin{tabular}{|c|c|c|c|c|c|c|c|c|}
\hline \multirow[t]{2}{*}{ Elements of CBIT Technophobia } & \multicolumn{7}{|c|}{ Components } & \multirow[t]{2}{*}{ CEI } \\
\hline & 1 & 2 & 3 & 4 & 5 & 6 & 7 & \\
\hline $\begin{array}{c}\text { I cannot use CBIT for farm } \\
\text { demonstration }\end{array}$ & .630 & & & & & & & .699 \\
\hline $\begin{array}{l}\text { As a VEA I don't need CBIT for field } \\
\text { work }\end{array}$ & .715 & & & & & & & .589 \\
\hline $\begin{array}{l}\text { Because of my age I prefer face to face } \\
\text { method of extension }\end{array}$ & .639 & & & & & & & .635 \\
\hline $\begin{array}{l}\text { Members of my social group do not } \\
\text { understand application of CBIT }\end{array}$ & .579 & & & & & & & .534 \\
\hline I find the buttons too tiny and fragile & & .633 & & & & & & .693 \\
\hline $\begin{array}{l}\text { I have busy schedule to bother myself } \\
\text { with CBIT }\end{array}$ & & .789 & & & & & & .663 \\
\hline Learning CBIT is difficult & & & .736 & & & & & .686 \\
\hline Learning to use CBIT is a complex & & & .759 & & & & & .695 \\
\hline Learning CBIT takes time & & & .678 & & & & & .652 \\
\hline $\begin{array}{l}\text { CBIT is difficult to use due to lack of } \\
\text { previous training }\end{array}$ & & & & .785 & & & & .666 \\
\hline $\begin{array}{l}\text { I don't have enough experience to use } \\
\text { CBIT }\end{array}$ & & & & .691 & & & & .605 \\
\hline $\begin{array}{l}\text { Learning to use CBIT largely depends } \\
\text { on sex }\end{array}$ & & & & & .737 & & & .646 \\
\hline $\begin{array}{l}\text { I fear using CBIT because of the } \\
\text { possibility of damaging the computer }\end{array}$ & & & & & .680 & & & .600 \\
\hline $\begin{array}{l}\text { I cannot use CBIT in rural areas where } \\
\text { I work with farmers }\end{array}$ & & & & & & .751 & & .689 \\
\hline $\begin{array}{l}\text { I don't know how to use new forms of } \\
\text { technology like Android }\end{array}$ & & & & & & & .508 & .589 \\
\hline lack of interest in CBIT & & & & & & & .874 & .801 \\
\hline \multicolumn{9}{|l|}{ Diagnostic Statistics } \\
\hline Initial Eigenvalues & 3.461 & 1.851 & 1.641 & 1.460 & 1.566 & 1.122 & 1.019 & \\
\hline$\%$ of variance & 19.230 & 10.285 & 9.117 & 8.112 & 6.476 & 6.232 & 5.662 & \\
\hline Cumulative \% & 19.230 & 25.515 & 38.632 & 46.744 & 53.220 & 59.453 & 65.114 & \\
\hline
\end{tabular}

Table 4: Factors Influencing CBIT Technophobia

1=Human, 2=Operational, 3=Learning, 4=Literacy, 5=Technological,

6=Environmental 7=Self - Efficacy

Extraction Method: Principal Component Analysis

Rotation Method: Varimax with Kaiser Normalization

a.Rotation Converged in 13 Iterations

\subsection{Hypotheses}

- $\mathrm{Ho}_{1}$ : There is no significant relationship between Personal Characteristics of Akwa Ibom ADP Personnel and CBIT technophobia

Four personal characteristics of respondents viz: sex, marital status, job status and educational status were subjected to Chi-square test to determine whether there exists a relationship between these selected personal characteristics and their level of CBIT technophobia. Educational status showed $\left(\mathrm{X}^{2}=22.541, \mathrm{P}<0.05\right)$ a significant relationship on CBIT technophobia. The relationship between education level and level of CBIT technophobia implies that education influences the level of CBIT technophobia among Akwa Ibom ADP personnel. This suggests that the higher the level of education, the lower the level of CBIT technophobia. Thus, the null hypothesis for the relationship between educational status and CBIT technophobia is hereby rejected. Conversely, the relationship between $\operatorname{Sex}\left(\mathrm{X}^{2}=3.635^{\mathrm{a}}, \mathrm{P}>0.05\right)$, Marital Status $\left(\mathrm{X}^{2}=3.143^{\mathrm{a}}, \mathrm{P}>0.05\right)$, Job Status $\left(X^{2}=19.808\right.$ a,$\left.P>0.05\right)$ are accepted. The results are contained in Table 5. This finding affirms Ubom's (2015) result in terms of the relationship between sex and marital status. 


\begin{tabular}{|c|c|c|c|c|c|c|c|}
\hline Item & Variables & $\begin{array}{c}\text { Chi -Square } \\
\text { Value }\end{array}$ & Df & $\begin{array}{c}\text { Asymp } \\
\text { Sign }\end{array}$ & $\begin{array}{c}\mathbf{P} \\
\text { Value }\end{array}$ & Remark & Decision \\
\hline 1 & Sex & $3.635^{\mathrm{a}} 3.143^{\mathrm{a}}$ & 2 & .162 & 0.05 & Not Significant & $\mathrm{H}_{0}$ : Accepted \\
2 & Marital status & $19.808^{\mathrm{a}}$ & 4 & .534 & 0.05 & Not Significant & $\mathrm{H}_{0}$ : Accepted \\
3 & Job Status & $22.541^{\mathrm{a}}$ & 8 & .071 & 0.05 & Not Significant & $\mathrm{H}_{\mathrm{o}}$ : Accepted \\
4 & $\begin{array}{c}\text { Educational } \\
\text { Level }\end{array}$ & $10.400^{\mathrm{a}}$ & 4 & .000 & 0.05 & Significant & $\mathrm{H}_{0}$ : Rejected \\
\hline
\end{tabular}

Table 5: Test of Relationship between Personal Characteristics of Respondents and CBIT Technophobia

- $\mathrm{Ho}_{2}$ : There is no significant difference in the level of CBIT technophobia between Field Extension Personnel (FEP) and Supervisory Extension Personnel (SEP) of Akwa Ibom ADP.

The study compared the level of CBIT technophobia of Field Extension Personnel (FEP) and Supervisory Extension Personnel (SEP) using the student's t-test. The group statistics revealed that FEP have a higher mean score of CBIT technophobia $(\overline{\mathrm{X}}=.5762, \mathrm{SD}=.1178)$ than SEP $(\overline{\mathrm{X}}=.5556, \mathrm{SD}=.13426)$. As shown in Table 6 the level of significance obtained from the analysis $(\mathrm{P}=.357)$ was greater than $(\mathrm{P}>0.05)$. The null hypothesis is therefore accepted. The measure of relationship (effect size) on the level of CBIT technophobia between the two groups was calculated using Cohen's (d) test which gave a value of 0.2 , which was interpreted to have no effect between the observed variations of the respondents. This implies that the level of CBIT technophobia of FEP and SEP do not vary significantly.

\begin{tabular}{|c|c|c|c|c|c|c|c|c|}
\hline Group & Number & Mean & SD & DF & T - Value & Sig & \multicolumn{2}{|c|}{ Cohen (d) test } \\
\hline FEP & 143 & .5762 & .11779 & 178 & .924 & .357 & .2 \\
\hline SEP & 37 & .5556 & .13426 & & & & \\
\hline
\end{tabular}

Table 6: Test of Difference in the Level of CBIT Technophobia between

Field Extension Personnel and Supervisory Extension Personnel of AKADEP

\section{Conclusion}

CBITs are technologies known to augment and facilitate extension work in the dissemination of agricultural information to a large number of beneficiaries, especially in remote areas at a minimal cost. The uses of these applications have not been fully exploited by extension personnel due to technophobia. It is against this background that the study sought to ascertain the dimensions of CBIT technophobia among extension personnel in Akwa Ibom State.

The study revealed that majority of the respondents had no formal computer training; this implies a non-computer literate workforce. Computer literacy and experience in the use of CBIT is the bedrock for ameliorating the effect of CBIT technophobia. The study also showed that majority of the respondents exhibited a moderate to high level of CBIT technophobia. This implies that CBIT technophobia may exacerbate particularly as ICTs continue to evolve in sophistication.

Furthermore, the study revealed: human-related, operational, learning anxiety, lack of exposure and experience, technological, environmental and self-efficacy variables; as factors that influence CBIT technophobia. CBIT technophobia between field extension personnel and supervisory extension personnel did not differ significantly among respondents in the study area. The study however revealed that educational status has significant relationship with CBIT technophobia. Thus, it can be concluded that CBIT technophobia is influenced by educational status, and that, the key driving factor for the level of CBIT technophobia among respondents in the study area is the lack of basic computer training.

\section{Recommendations}

Based on the findings of this study the following policy recommendations were made.

- The Government should facilitate the evolution of appropriate CBIT policies chiefly by making computer literacy as part of the mandatory requirement for employment of personnel.

- Management should give financial incentive to staff to attend computer training. Such training could be personal or organised by the management of AKADEP for all extension staff to participate. Similarly, Akwa Ibom ADP could liaise with agricultural organisations that are known for the development of ICT skills to facilitate tailor-made ICT training based on the identified skill gaps.

- To reduce the level of technophobia, personnel should be frequently exposed to CBIT facilities, and extension work environment should be such that it encourages personnel to become CBIT self-efficacious.

\section{References}

i. Ahmad S., A., Kamba M., A. and Usman, M. (2012). Technophobia Versus ICT Acceptance and Use in Teaching and Learning Among Academic Staff of Universities in Northern Nigeria. Paper presented at the British Educational Research Association Annual Conference, University of Manchester, U.K. 4-6 September.

ii. Ben-Jacob, M. G. and Liebman, J. T. (2009). Technophobia and the Effective use of library Resources at the College/University level. Journal of Educational Technology Systems 38(1): 33-38 
iii. Bhattacharjee, A. and Raj, G. (2010). Social Media: Shaping the Future of Agricultural Extension and Advisory Services. A Global Forum for Rural Advisory Services. 38 PP.

iv. Chau, P., Y., K., and Hu, P. J. (2002) Examining a Model of Information Technology Acceptance by Individual Professionals on Explanatory Study. Journal of Management Information systems 18(4): 191- 229

v. Ezeano, C., I, Matthew -Njoku, E.C, Ezeano CA and Isife B.I (2008). Agricultural Extension Policies and Information and Communication Technologies. In: Proceedings of the13th Annual National Conference of the Agricultural Extension Society of Nigeria, Umudike, Abia State, Nigeria, April 2008.

vi. Fadiji, T. 0. (2007). The Effectiveness of Sources of Information and Farmers' Awareness of `Farm Practices in Rural Communities of Kaduna State, Nigeria.

vii. Ha J., G., Tom P. and Gisli T. (2011). A Study on Technophobia and Mobile Device Design International Journal of Contents, 7(2):17-25.

viii. Kase, S., E. and Ritter, F., E. (2009). Gender and Computer Anxiety.

ix. Lawal-Adebowale, O. A. and Oyekunle, O. (2014). Agro-students' Appraisal of Online Registration of Academic Courses in the Federal University of Agriculture Abeokuta, Ogun State Nigeria. International Journal of Education and Development using information and Communication Technology, 10 (4):139- 154.

x. Nyirongo, K., N (2009), Technology Adoption and Integration: A Descriptive Study of a Higher Education in Developing Countries, Virginia, Virginia Polytechnics Institute and State University. PhD Thesis.

xi. Olufemi O., A and Oluwatayo, O., J (2014) Computer Anxiety and Computer Knowledge as Determinants of Candidates' Performance in Computer-based Test in Nigeria. British Journal of Education, Society and Behavioural Science.4 (4):495-507

xii. Omotayo, O., M. (2011), ICT and Agricultural Extension: Emerging Issues in Transferring Agricultural Technology in Developing Countries: In: Madukwe M. (ed) Agricultural Extension in Nigeria. Ilorin: Agricultural Extension Society of Nigeria (AESON), Nigeria, Pp200 - 215

xiii. Porter, C., E. and Donthu, N. (2006). Using the Technology Acceptance Model to Explain How Attitudes Determine Internet Usage: The Role Of Perceived Access Barriers and Demographics Journal of Business Research 59 (2006): 999.

xiv. Reed, K., Doty, H.D., and May, D.R. (2005). The impact of aging on self - efficacy and computer skills acquisition. Journal of Managerial Issues 17(1): 212- 228.

xv. Rheingold, H., Smart Mobs (2002); The Next Social Revolution- Transforming Cultures And Communities In The Age Of Instant Access, Cambridge, MA, USA,

xvi. Riggs, M. (2010).e -Agriculture and the Millennium Development Goals: WSIS interview with Michael Riggs, Retrieved from http;//www.eagriculture.org/news/e-agriculture- and mdgs-wis-interview-michael-riggs-0 -1007

xvii. Salau, E. S. (2013). Use of Information and Communication Technologies by Non- Governmental Organizations for Agricultural Development in Nasarawa State, Nigeria, Unpublished PhD Thesis, University of Nigeria

xviii. Sami, L,K. and Pangannaiah, N. B.(2006) Techno stress: A literature Survey on the Effect of Information Technology on Library Users, Library Review, 55(7): 429-439, (Accessed: July 2015)

xix. Ubom S., A. (2015). Levels of computer anxiety among extension personnel in Uyo Agricultural zone of Akwa Ibom State Agricultural Development programme: Unpublished Undergraduate Project, University of Uyo.

xx. Wang, K., Shu, Q. and Tu, Q. (2008). Techno Stress under different Organizational Environments: An Empirical Investigation. Computers in Human Behaviour 24(6):3002- 3013

xxi. Zinn, S (2009) Readiness to Adopt E- Learning: Pioneering A Course In School Liberianship Education. South African Journal of Libraries and Information Science 75(2):159-169 